\title{
Ekonomi dan Kemiskinan Tinjauan Agama
}

\author{
Oleh : Musa Asy'arie
}

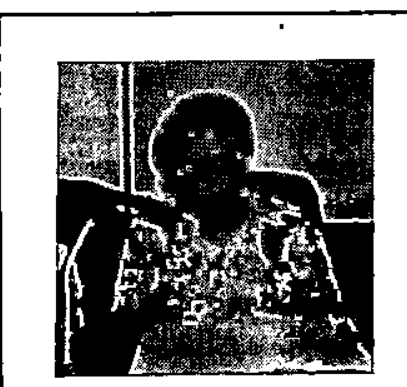

Musa Asy'arie, dilahirkan di Pekalongan pada tanggal 31 Desember 1951. Alumnus.Fakultas Ushuluddin IAIN Sunan Kalijaga Yogyakarta. Sedangkangelar Doktomya diraih dari Pasca Sarjana IAIN SUKA, dan saat ini sebagai staf pengajar pada almamaternya. Selain itu ia uga sebagai pengusaha industri pengecoran besi di Ceper, Klaten serta Ketua Umum Koperasi Industri Batur, Jaya Klaten. Beberapa karya tulisnya yang telah diterbitkan antara lain : Konsep Manusia sebagai Penduduk Kebudayaan dalam Al Quran dan Agama Kebudayaan dalam Pembangunan.

Persoalan kemiskinan adalah persoalan yang kompleks dan berdimensi ganda, spiritual dan material dan mempunyai kaitan dengan berbagai aspek kehidupan $^{1)}$, ia selalu ada sebagai realitas hidup yang berdiri bersebelahan dengan kekayaan, seperti realitas siang atau malam, dan terang atas kegelepan.

Kemiskinan sebagai realitas kehidupan, selalu digambarkan sebagai suatu keadaan kehidupan yangkekurangan, lemah dan tidak berkecukupan dalam memenuhi kebutuhan hidupnya, baik dalam pengertian spiritual maupun material. Kemiskinan spiritual menggambarkan situasi kehidupan batin seseorang yang tak pernah merasa puas dengan apa yang dimiliki dan diperolehnya, yang selalu tak méncukupi untuk memenuhi keinginnan dan kebutuhannya. Agama menyebutnya sebagai orang yang tidak dapat bersyukur atas nikmat Tuhan. Sedangkan kemiskinan material bersifat ekonomis, yaitu penghasilan diperolehnya sangat rendah, yang dapat mencukupi untuk memenuhi kebutuhan fisik minimum. ${ }^{2)}$.

Kemiskinan spiritual bisa saja terjadi pada kehidupan seseorang yang secara ekonomis mempunyai penghailan yang mencukupi, bahkan berlebihan untuk memenuhi kebutuhan hidupnya, dan seringkali digambarkan sebagai sebuah kehidupan batin yang sakit, yang seringkali berkembang ke arah perbuatan yang a sosial, dan bahkan menjurus kriminal. Kemiskinan spiritual mungkin lebih berbahaya dari kemiskinan material, bahkan kemiskinan material ini seringkali sengaja diharapkan, dan menjadi pilihan hidupnya, agarmanusia terbebas dari penderitaan batin. Dalam kalangan sufi tertentu, kekayaan dipandang sebagai penghalang bagi usaha menuju pencapaian yang Ilahiyah dengan Tuhannya. 
Kemiskinan apapun bentuknya, sebagai suatu realitas kehidupan, sepenuhnya tak dapat dihilangkan, kemiskinan hanya dapat diubah, dikurangi ataupun diperbaiki, agar tidak menghancurkan derajat kemanusiaannya. Kekayaan adakarena kemiskinan dan orang menjadi kaya karena adanya orang yang miskin, tanpa ada orang miskin tak akan pernah ada orang kaya. Karena itu, orang kayadan orang miskin saling membutuhkan untuk memberikan. arti pada makna kehidupannya sendiri,dan dapatsaja ukuran kekayaan dan kemiskinan itu, antara bangsa yang satu dengan bangsa yạng lainnya berbeda; baikkualitasmaupunkuantitasnya.

Kemiskinan seperti yang akhir-akhir ini dibicárakan oleh banyak kalangan, pejabat, pemerintah, kalangan akademis dan cendekiawan, dan di kalangan masyarakat umumnya, yang kononnya jumlahnya sudah turun menjadi 25,9 juta, yang berada di desa-desa tertinggal adalah lebih ditekankan pada kemiskinan dalam kaitannya dengan ekonomi, yaitu sebagai realitas dari sistem perekonomian yang timpang ${ }^{3)}$, séhingga mengakibatkan yang kaya makin kaya dan yang miskin makin miskin, yang menyulut rasa ketidak puasan masyarakat karena ketidak adilan terasa makin melebar ke berbagai aspek kehidupan, yang kemudian mempertegas munculnya berbagai kesenjangan dạn ketidak-berdayaan.

Dalam kehidupan politik kită, rakyat yang miskin hanyalah menjadi objek dan' alat politik untuk melegitimasi kekuasaan. Makna kedaulatan rakyat menjadi semu dan seringkali bahkan rakyat tidak mempunyai kedaulatan sama sekali. Kemiskinan menjadikan munculnya ketidak berdayaan politik dan rakyat yang miskin dengan sendirinya menjadikannya kehilangan hak-hak politiknya. $\left.{ }^{4}\right)$

$\because$ Dalam kehidupan hukum kita, keadilan rasanya tidak banyak berpihak pada orang-orang yang miskin, yang lemah, perbedaan hukum atas orang-orang miskin terlihat pada perilaku aparat hukum yang membedakan perlakuan sangat mencolok antara yang kaya, yang kuat dan yang miskin, yang lemah, bahkan yang kaya'bisa saja membeli keadilan dan -merekayasa proses hukum, sebagaimana yang seringkali diberitakan pada media kita, seperti kasus Sengkon dan Karta, kasus penggusuran tanah petani untuk mendirikan lápangan golf dan seterusnyà.

Dunia pendidikan kita berkembang menjadi kian mahal, shingga tak memungkinkan orang-orang miskin melanjutkan pendidikannyakejenjang yang lebih tinggi, sehingga ketidak berdayaan itu makin mengukuhkan struktur ekonomi yang timpang pada kehidupan masyarakat kita. Tingkat kebodohan yang makin meluas pada kehidupan orang-orang miskin pada gilirannya akan memperkuat 'adanya kemiskinan yàng makin șulit diatasi karena struktural sifatnya.

Dalam kehidupan beragamá, kemiskinanjuga dapatmemperlemah iman. Banyak kasus, pindah agama karena kemiskinan dan biasanya kemiskinan mengakibatkan jual beli agama. Konon, Nabi Muhammad saw pemah menegaskan . bahwa kemiskinan dapatmembawa kepada kekufuran. Meskipun demikian, agama tidak pemah merendahkan orang-orang miskin, karena kaya dan miskin hanya berlaku dalam tata pergaulan manusia, bagi Tuhan semua manusia sama, dan 
dibandingkan dengan Tuhan, semua manusia adalah miskin."

Kemiskinan telah menciptakan ketidakberayaan dalam berbagaikehidupan manusia; sosial, ekonomi, politik, hukum, pendidikan dan budaya. Dantidak ada faktor penyebab tunggal dalam kemiskinan. Karenaitu, penanggulanngannya juga tidak dapat dilakukan hanya dengan pendekatan yang tunggal, dan juga diperlukan adanya pendekatan yang melibatkan berbagai disiplinilmu pengetahuan dan dari berbagai aspek kehidupan.

Agama sebagaimana yang banyak diyakini oleh pemeluknya adalaha datang dari Tuhan, melalui orang-orang yang terpilih untuk menyampaikan ajaran-Nya, yang tersurat dalam kitab suci dan tersirat dalam tanda-tanda-Nya yang terbit dari segala penjuru alam semesta ini. Agama dimaksudkan sebagai pedoman hidup bagi manusia.")

Dalam setiap agama, keyakinan kepada Tuhan adalah dasar pertama dan yangpertama. Oleh pemeluk agama, Tuhan diyakini sebagai Yang Mahakuasa, yang menciptakan segala sesuatu, yang kèlak akan meminta pertanggungjawaban atas perbuatan manusia ciptaan-Nya itu. Keyakinan ini membawa pemeluk agama pada ketulusan untuk mengabdikan diri kepada-Nya; yang menimbulkan efek psikologis yang diliputi oleh ketakutan, cinta kasih dán pengetahuan. Efek psikologis inilah sesungguhnya yang -membentuk nuansa yang unik dalam perilaku keagamaan. ${ }^{\text {? }}$

Sebegai pedoman hidup bagi manusia, maka setiap agama selalu memperhatikan realitas hidup manusia, sehingga jika realitas itu berbeda, maka agama memberikan tempat agar perbedaan realitas itu berkembang secara harmonis, melalui penyadaranmengenai eksistensinya bahwa kedudukan manusia dihadapan Tuhan pada hakikatnya adalah sama, sederajat, senasib, sepenanggungjawaban. Oleh karena itu, agama dilihat dari sisi Tuhan pada hakikatnya adalah sama, karena Tuhan yang menciptakan agama dan manusia yang berbeda-beda itu pada hakikatnya kembali kepada Tuhan Yang Satu jua. Yang tidak pernah ada duanya, yanghanyakarenaperbedaan lisanmanusia, maka manusia dalam melisankan Tuhan pun kemudian menjadi berbeda, sebagaimana perbedaan lisan manusia dalam melisankan realitas batu yang sama. ${ }^{8)}$

Perbedaan agama antara satu dengan lainnya, pada dasamya lebih disebabkan karena adanya perbedaan realitas hidup manusia, yaitu perbédaan waktu, tempat dan tantangan, yang kemudian mewamai pula nuansa keagamaan yang turun dengan sepenuhnya mempertimbangkan realitas itu.Perbedaan realitas itulahyang kemudian menampilkan wajah keagamaan dan keberagamaan seseorang berbeda antara satu dengan lainnya.

Dalam hubungan ini, pengajaran àgama seharusnya memperhatikan secara seksama terhadap realitas hidup manusia. Wajah dan pesan agama seharusnya didasarkan pada pehamanan yang benar dan tepat terhadap realitas. Agama sesungguhnya tidak anti realitas. Agama jugatidak a historik. Agamamelihat realitas untuk diubah kualitasnya menjadi Ilahiyah.

Dalam konteks kemiskinan, agama seharusnya memerangi kemiskinan, karena kemiskinan pada dasamya merupakan ancaman dan tantangan bagi keragamaaan. 
Oleh karenaitu, institusi agama seharusnya menjadi institusi yang secara konsisten melakukan pembelaan terhadap kaum miskin, yanglemah. Membela orang-orang yang miskin itu bukan hanya sekedar menyântuninya, danmenghiburnyadengan harapan sorgawi kelak, tetapi harus dengan "berjihad" agar kemiskinan bisa diubah dan ditata sehingga penindasan pada kaum yang lemah dan yang miskin tidák merajalela dan wajah kehidupan menjadi lebihmanusiawi. Tentunyadiperlukan suatu konsep yang tepat, yang tentu saja tidak sederhana, karena menanggulangi kemiskinan tidak semudah membalik tangan.

Dalam pandangan agama, semua yang ada, alam semesta seisinya adalah ciptaan Tuhan dan milik Tuhan'). Manusia adalah salah satu bagian dari ciptaan-Nya: Di hadapan Tuhan, posisi kodrat manusia adalahciptaan-Nya, yang bawaan kodratnya adalah tunduk sepenuhnya pada hukumhukum Tuhan yang ditetapkan dalam setiap ciptaan-Nya, ia pun tidak pernah terlepas kehidupannya dari proses tumbuh, berkembang dan mati.

Kelebihan manusia daripadaciptaan Tuhan lainnya adalah bahwa ia dikaruniai aqal ${ }^{10)}$, dan dengan aqainya manusia dapat berperan sebagai pencipta kedua yaitu kebudayaan ${ }^{11)}$. Posisi kreatif sebagai pencipta kedua yang membentuk kebudayaan ini, menempatkan manusia sebagai wakil Tuhan di muka bumi, sebagai teman kerja Tuhan, co-worker of Göd.

Dalam kondisi ini, kekayaan yang dimiliki pada hakikatnya dari proses yang melibatkan faktor-faktor eksternal yang antara lain berupa sumber daya alam disekitar hidupnya dan juga orang lain di
luarhidupnya:Oleh karena itu, dalam setiap proses yang melahiikan kekayaan pada dàsarnya tidak dapat dimiliki oleh individu secara mutlak. Dalam pandangan agama, pemilikan mutlak tidak dapat dikenakan kepada manusia, pemilik mutlak ada yang ada hanyalah Tuhan sendiri. 'Al Qur'an sendiri menegaskan bahwa dalam setiap harta benda yang dimiliki seseorang, terdapat pula hak orang lain di dalamnya ${ }^{12}$.

Oleh karena itú, semua agama rasanya telah menegaskan dan menetapkan kewajiban kepada pemeluknya untuk menolong dan memperhatịkan nasib sesamanya, dan memberikan kelebihan yang dimilikinya untuk membantu orang lain yang kekurangan, baik kekayaan, keilmüan, ataupun kekuasaan. Al Qur'an bahkan menegaskan bahwa para pendusta agama adalahmereka yang mentelantarkan anak-anak yatim dan tak mau memberikan makan orang yang miskin ${ }^{13}$.

Dalam pandangan agama, kekayaan adalah baik. Al Qur'an bahkan menegaskan bahiwa anugerah (kekayaan) adalah janji Tuhan, sedangkan kemiskinan (kefakiran) adalah janji syaitan ${ }^{14)}$. Karena kekayaan adalah kebaikan, makacaramemperolehnya harus dengan cara yang baik. Kekayaan yang diperolehnya dengan cara yang tidak baik, mencerminkan suatu kemiskinan ruhani. Kemiskinan ruhani inilah yang biasanya mendorong pemiliknya untuk menggunakan kekayaannya untuk tujuantujuan yang seringkali berlawanan dengan moralitas. Oleh karena itu, kekayaan materi seharusnyamenjadi cerminan dari kekayaan ruhani, atau paling tidak kekayaan materi seharusnya menjadikan ruhaninya juga kaya, sehingga kekayaan yang dimilikinya mempunyai makna sosial. 
Oleh karena kekayaan adalah kebaikan, maka para pemeluk agama juga dianjurkan untuk mendapatkannya, tentunya dengan cara-cara yang dibenarkan oleh moral agama. Dalam agama cara dan tujuan merupakan kesatuan yang tak terpisahkan ${ }^{15)}$. Dan dalam Islam sendiri untuk dapat melaksanakan rukun.Islam yang lima, diperlukan adanya kekayaan antara lain untuk memenuhi rukuni Islam yang empat yaitu zakat dan yang lima yaitu haji.

Untuk menanggulangi kemiskinan, dari sudutpendekatan agama, kiranya perlu dipertimbangkan beberapa hal, yaitu :

\section{Institusi agamá harus menjadi pusat pembelaan kaum lemah dan miskin.}

Peran agama hárus dirumuskan kembali terus menerus secara aktual dan köntekstual melalui institusi agamanya masing-masing, karena sesungguhnya dalam setiap sejarah agama, terdapat saling kaitan antara sebab turunnya agama realitas ummat, dan agama diturunkan sebagai usaha perbaikan kualitas ummat tersebut. Nabi Muhammad saw., juga menegaskan dirinya diutus untuk menyempurnákan budi pekerti luhur.

Oleh karena situasi dan kondisi kehidupan suatu ummat itu berbeda, baik lokasinya, lingkungan alamnya dan tingkat kebudayaannya, maka setiap pengajaran agama yang hendak dikembangkan dalam suatu masyarakat tertentu,, mesti harus memperhatikan dan dirumuskan sesuai tuntutan realitas masyarakat tersebut. Pengajaran agama untuk masyarakat industri tentunya lain dengan pengajaran ágama untuk masyarakat agraris, demikian pula halnya untuk masyarakat yang kaya dan dengan masyarakat yang miskin.

Setiap masyarakat sesungguhnya mempunyai rasionalitasnya sendiri-sendiri. Rasionalitas buat masyarakat industri tentu Iạin dengan rasionalitas mienurut masyarakat agraris. Buat masyarakat industri, adalah rasional untuk menggunakan semua waktu untuk mencapai target produksi, kalau perlu 24 jam perusahaan bckerja penuh, karena waktu dipandangnya sebagai gerak linier, sedangkan bagi masyarakat agraris adalah rasional untuk mengejar produktivitas berdasarkan aturan alam, karena waktu dipandangnya sebagai gerak siklus. Nabi Muhammad saw., sendiri menegaskan perlunya berbicara kepada masyarakat sesuai dengan kadar rasionalitasnya masingmasing ${ }^{16)}$.

Dalam kaitanini, persoalannyaterletak pada institusi agama sebagai pusat pelayanan dan pembelaan kaum yang lemah dan miskin, baik material ataupun spiritual, untuk terus menerus merumuskan dan menyesuaikan dirinya dengan perubahan;" agar proses perubahan dapat dikembangkan untuk mernperteguh kemanusiaan.

\section{Kebebasan kreatif}

Agar institusi agama dapat memerankan dirinya dalam perubahan sosial secaraaktual maka kebebasan kreatif harus dipandang sebagai bagian dari kehidupan internal institussi keagamaan tersebut. Karena tanpa adanyakebebasankreatif yang diberlakukan secara intemal dalam institusi agama, maka akan terjadi kesenjangan antara institusi agama dengan realitas perubahan.

Kebebasan kreatif bukanlah aancaman bagi iman, akan tetapi justru sebagai basis tumbuhnya iman yang sehat, yang peduli dengan , realitas kemiskinan, keterbelakangan dan ketidak adilan. Iman 
yang sehat adalah iman yang terlibat dengan tantangan yang dihadapi oleh masyarakat, bukan iman yang dipasung dalam dinding formalisme keagamaan.

Dengan kébebasan kreatif yang dikembangkan secara internal dalam institusi keagamaan, maka institusi keagamaan itu pada gilirannya akan dapat menumbuh kembangkan kreatifitas dalam masyarakat. Karena kreatifitas pada hakikatnya merupakan faktor yang amat vital dalam usaha masyarakat mengatasi problematikanya, masyarakat yang tidak kreatif adalah masyarakat yang sulit maju,' apalagi untuk mengentaskan kemiskinan.

\section{Peningkatan solidaritas di sektor produktif}

Pengalaman dalam kegiatan pembinaan industri kecil di daerah pedesaan, menunjukkan bahwaciri paguyuban ${ }^{17}$ yang seringkali dinyatakan oleh para ahli ilmu sosial bagi masyarakat pedesaan-kita, temyata tidaktercermin lagi dalam kegiatan ekonomi. Dalam kegiatan ekonomi, terutama dalam masyarakat industri $\cdot \mathrm{di}$ pedesaan, berlangsuing proses kanibalisme, dimána yang kuat cenderung menjadi ancaman bagi kelangsungan hidụp bagi yang kecil.

Kejatuhan pusat-pusat industri kecil pedesaan, biasanyadimulaioleh munculnya persaingan antara mereka yang cenderung tidak sehat, seperti kejatuhan masyarakat pertenunan di Pekalongan, Solo, Tasikmalaya, dan juga kerajinan emas di desa Paesan Pekalongan dan mungkin ditempat-tempat lainnya.

Jika dikaji secaramendalam, memang tidak ada penyebabtunggal yangmengakibatkan jatuhnya masyarakat industri pedesaan itu, semua faktor yang berasal dari dinamika internal maupun eksternal memang mempunyai andil, baik sosial, ekonomi, politik', budaya dan agama. Namun demikian, jika diamatilebihlanjut, temyata bahwa mereka yang dapat menyelematkan dirinya dari kejatuhan adalah mereka yang màmpu mengantisipasi perubahan secara kreatif, bahkan memberikan peluang untuk berkembang lebih maju.lagi.

Untuk itu, solidaritas di sektor produktif, kiranya perlu dijaga dan dikembangḱan, seperti yang biasanya dimiliki oleh para imigran dan berbagai suku ataupun kelompok masyarakat. Apalagi dalam era menguatnyà keinginan untuk mengembangkan dan membina ekonomi rakyat dalam PJPT II nanti, karena tanpa makin menguatnya solidaritas di sektor produktif, maka ușaha membangun ekonomi rakyat akan mengalami banyak : hambatan.

Dalam hubungan ini; agama kembali dapat memainkan perannya untuk mengembangkan ajarannyá bahiwa tidak ada pemilikan individual yang bersifat mutlak. Agama manapun mengajarkan bahwa pemilikan kolektif lebih mulia daripada pemilikan individual. Pemilikan individual diakui dalam keseimbangannya dengan kewajiban-kewajibannya yang bersifat sosial.

\section{Etos kerja}

Kemiskinan pada hakikatnya juga berhubungandenganetos kerja, dan rasanya agama mempunyai andil yang cukup besar dalam merumuskan etos kerja.

Pada sebagian besat masyarakat beragama kita, kaya dan miskin masih dipandangnya sebagai takdir Tuhan. Jika anggapan ini 
diteruskan, maka yang dapat mengubah kemiskinan hanyalah Tuhan sendiri. Pandangan keagamaan yangdemikian, akan menambah usaha penanggulangan kemiskinan yang sulit itu menjadi makin sulit.

Di sini, peran agama kembali dipersoalkan, apakah pandangan pemikiran keagamaan bahwakaya dan miskin adalah takdirmasih perlu diajarkan dalam masyarakat yang sedang berusaha mengentaskan kemiskinan?

Kiranya rasionalitas agama perlu dikembangkan, agar jangan suatu agama yang menegaskan bahwa tangan di atas lebih mulia daripada tangan di bawah diharapkan dapat menjadi mitos kerja yang dapat membangkitkaan kesadaran atas harkat dan martabat dan harga diri seorang. beragama.

Dalam kaitanini, maka kesufian tidak perlu lagi dicapai melalui pemiskinan dan membelakangi dunia, tetapi ada dalam kancah memerangi kemiskinan dan keterlibatan dirinya secara intens dalam persoalan keduniaan, dengan memberikan wawasan iman yang lebih kuat.

Kemiskinan

adalah kemiskinan rohani

Kekayaan

adalah kekayaan rohani

adakah kekayaan dicapai

dengan kemiskinan rohani

kemiskinan adalah kemiskinan diri

yang lemah iman

iman bukan lagi yang dibendakan

imanidalam yang dikerjakan

iman pada hakikatnya ada

teruji dalam laku

dalam kerja

kerja meniru yang diimani

kerja meniru Ilahi

kata Nabi

Tirulah Tuhan

tetapi bukan menjadi Tuhan

karena manusia tidak akan pernah kuasa menjadi Tuhan.

dengarkan kata Tuhan

dalam diri kecilmu

dalam kesejatianmu sendiri

dalam lakumu

menapaki jejak-jejak Ilahi 


\section{CATATAN KAKI :}

1) Dalam pandangan Marx dan Engles misalnya, sejarah seluruh masyarakat manusia, dari dulu dan sekarang merupakan sejarah perjuangan klas. Tarik menarik antara tuan dan hamba, kaum ningrat dan kaum jelata, raja dan hamba, pendeknya antara kaum penindas dan tertindas. (Lihat : Lewis Coser, Sociological Theory, Macmillan Publishing, USA, 1982, hal ; 551). Sedang Peter berger melihat bahwa sejarah umat manusia merupakan sejarah penderitaan yang mengeksplisitasikan suatu jumlah korban manusia dalam menanggung beban sejarah (Lihat : Peter L Berger, Piramida Korban manusia, LP3ES, Jakkarta, 1982, hal : 193). Tak pelak, memang kemiskinan sendiri sesungguhnya bukan saja kompleks, tetapi merupakan stigma sosial yang rumit dan butuh analisis dan problem-solving yang holistik.

2) Sepertiditunjukkanoleh Yusuf Qordhawi, pendirian manusia terhadap problema kemiskinan sesungguhnya berbeda-beda, diantaranya, golongan yang mensucikan kemiskinan yang menganggap bahwa kemiskinan bukan suatu keburukan, tetapi karunia Allah. Golongan Jabariah meyakini bahwa kemiskinan merupakan taqdir Allah atau sesuai dengan iradat Allah. Sedang golongan yang mengajak berbuatkebajikan secara pribadi berpendirian bahwa kemiskinan merupakan problem yang perlu diatasi dan dipecahkan. Golongan kapitalisme memandang bahwa kemiskinan termasuk salah satu bahaya kehidupan, akan tetapi menjadi tanggung jawab si miskin itu sendiri, yang penting ia bukan menjadi beban umat, negara dan hartawan. Dan golongan sosialisme-Marxisme berpendapat bahwa melenyapkan kemiskinan dan berusahamenyadarkan orang-orang miskin adalah suatu hal yang tidak mungkin tercapai kecuali apabila golongan Borjuis dan sumber-sumber penghasilan dan kekayaan mereka dimusnahkan. (Lihat : Yusuf Qordhawi, 'ProblemaKemiskinan Apa Konsep Islam, Bina llmu, Surabaya, 1982, hal. 15-21)

Dalam pändangan kaum Marxis, misalnya, kaum proletar (kaum miskin) adalah istilah' teknis yang menunjuksuatukelas yang harus menjual tenaga buruh mereka kepada kelas kapitalis. Sebagian besar orang-orang miskin adalah baik petani maupun pemilikmodal kecil atau merekayang menjadibagian dari ekonomi informal dalam kota. Mark menyebut merekadengan istilah "Lumpen Proletariat".(Phillip Berryman, hal. 33)

Menurut Imam Nawawi Al-Banteni, dibedakan antara istilah faqir dan miskin. Faqir adalah mereka yang tidak mempunyai harta benda dan pekerjaan yang bisamencukupikebutuhan primemya seperti makan, pakaian, dan tempat tinggal. Sedang miskin adalah mereka yang mempunyai harta dan pekerjaan, tetapi tidak bisa mencukupi kebutuhan pokoknya. (Imam Nawawi, Nihayatuz Zain, Syirkah Al-Ma'arif, Bandung, hal. 179).

3) Gurnar Myrdal melihat kemiskinan dalam kondisi ini sebagai "Process of self poverty" yakni proses pemiskinan sendiri sedang Gusta Papanek menyebut dengan istilah "the few rich people among the poor million", yakni meruaknya fenomena beberapa gelintir orang kaya di tengah berjuta rakyat yang miskin.

Menarik untuk dijadikan perbandingan adalah hasil case studi dari Brigitte Erler tentang kemiskinan di Bangladesh. Erler melihat kenyataan bahwa kapitalisme dinegara berkembang tidak dapat dipisahkan dengan kekuasaan politik yang berkuasa. Hal inilah yang menyebabkan bantuan modal dari negaradonormenjadi tidaksampai secaramenyeluruh pada rakyat miskin. Erler menyebut dengan istilah "Bantuan mematikan".(Lihat:BrigitteErler, Bantuan Mematikan, LP3ES, Jakarta, 1989).

Untuk melawän kemiskinan di setiap masyarakat diperlukan kemauan politik yang kuat dalam masyarakat itu, dan terutama di kalangan pemimpin-pemimpin politik sendiri. Laju pertumbuhan yang makin besar bukan jaminan untuk melawan kemiskinan yang makin buruk. Kebijaksanaan distribusi harus menjadi bagian tak terpisahkan dengan pola dan organisasi produksi. (Lihat : Mahbub Al-Haq, Tirai-tirai Keniskinan. Yayasan Obor, Jakarta, 1983)

4) Kondisi politik seperti ini, seperti ditunjukkan oleh Mitchel Foucoult, sebagai menunjukkan bahwakekuasaan menjadi anonim dan fungsional, sehingga individu-individu menjadi mudah dipantau dan diidentifikasikan. Foucoult menyebut dengan istilah "a rezim of Discours" yang melumpuhkan, membekukan dan membentuk pluratlitas ke arah disain besar yang didefinisikans ebagai norma (Lihat: Mitchel Foucoult, Power dan Knowledge, The Harvester Press, 1980) 
Padahal sebenarnya, dalam masyarakat yang mengalami modernisasi sosial-ekonomi akibat perkembangan ekonomi pasar akan tumbuh kelas sosial yang menikmati kekuasaan ekonomi yang cukup besar sehingga mampu mengajukan tuntutan dan memaksa pemerintah untuk melakukan "bargaining" dengan mereka. Kelas inilah yang dikenal sebagai kelas menengah, yang mempelopori penciptaan politik yang lebih terbuka. (Lihat : S.M. Lipset, Political Man, Doubleday, New York, 1962)

5) Menurut Yusuf Qordhawi, hadits-hadits Nabi menunjukkan bahwa kemiskinan adalah satu hal yang sangat berbahaya terhadap individu dan masyarakat, akidah dan kepercayaan, fikiran dan kebudayaan, keluarga dan bangsa. (Lihat : Yusuf Qordhawi, ProblemaKemiskinan ApaKonsep Islam, Bina Ilmu, Surabaya, 1982, hal. 25)

Kemiskinan sesungguhnya merupakan pula persoalan teologis. Dalam konteks teologi liberal, misalnya, menurut Gustaro Gutierrez, kemiskinan (material) sebagai suatu kejahatan dan akibat dari penindasan beberapa orang terhadap sesamanya; kemiskinan yang mendehumanisasikan, makhluk hidupmerupakan perlawanan terhadap Tuhan. Untuk mengetahui Tuhan kita harus berusaha keras memberantas kemiskinan. (Philip Berryman, Liberation Theology, Parteon Books, New York, 1987, hal. 32)

Haruslah diakui bahwa penanggulangan masalah kemiskinan oleh berbagai agama, selama ini berkisar pada upaya karitatif untuk meringankan beban penderitaan warga masyarakat sebagai perorangan. Walaupun dilakukan usaha terorganisir untuk melakukan penanggulangan seperti itu, watak pelayanan individual atas mereka yang menderita itu masih terlihat nyata, sedang implikasi kemasyarakatannya baru sampai pada tingkat potensial belaka. Zakat sendiri sebagai lembaga dengan kemungkinan seperti itu, masih belum lagi dibenahi dengan tuntasoleh kaum Muslimin, sehingga belum dapat menjadi agregat ekonomi dalam artian penuh dan kongkrit. (Lihat : Abdurrahman Wahid, Muslim di Tengah Pergumulan, LEPPENAS, Jakarta, 1983, hal : 76).

Kenneth Boulding membedakan apa yang disebutnya "agama kependetaan" dan "agama profetik".Pada mulanya agama-agama besar seperti Yahudi, Kristen dan Islam bersifat profetik yang menggerakkan perubahan-perubahan besar atau transformasi masyarakat. Di sini agama bersifat profetik, tetapi kemudian setelah melembaga agama lalu menjadi rutin dan bahkan menjadi kekuatan konservatif (Koentowijoyo, Paradigma Islam, hal. 19, Mizan, Bandung, 1991)

8) Menurut Moch. Arkaun, harus dibedakan antara pandangan antrobiologi dan pandangan idiologi terhadap agama. Dalam pandangan I, menolak pandangan adanya superioritas satu agama, yakni pandangan adanya 'agama yang Haq', tetapi menurut pandangan ini yang terpenting adalah menurut agama, menguraikan dasar-dasar agama, ajaran-ajarannya, metodologi dan kisah-kisah di dalamnya serta menginterpretasikan rumusrumusnya dan dilektika metodisnya.

Dengan demikian, maka akan memperkukuh ruh toleransi atau keterbukaan dan fondasi kemerdekaan agama, bukan justru menolak terhadap kebenaran agama lain. Pandangan idiologi tertumpu pada menjelaskan keutamaan-keutamaan suatu agama.

Menurut Arkaun selanjutnya, agama sesungguhnya bila hanya difahami sebagai akidah, ibadah dan aturan sosial, maka tidak ada bedanya dengan Marxisme yang sama-sama menancapkan akidah penolakan terhadap kedzaliman persoalan masyarakat, dan meletakkan dasar aturan yang kukuh untuk mengatur persoalan masyarakat. Karena itu perlu dilakukan suatu ijtihad filsafat untukmemahami kembali agama (Arkaun, Al Islam Ashsholah wa alMumarasah, Marseille, Sorbionne, 1986, hal : 27)

Menurut Ibnu Arabi, Tuhan yang menjadi obyek penyembahan bukanlah dalam pengertian bahwa Dia hanyalah Tuhan orang Muslim, orang nasrani atau penganut agama-agana lain, akan tetapi dalam pengertian bahwa Dia adalah zat dari tiap sesuatu yang disembah. Dia tidaklah dibatasi oleh suatu kepercayaan atau bentuk agama tertentu manapun. Tiap-tiap sesuatu yang disembah adalah salah satu dari jumlah bentuk yang tak terbatas tempat dimana Tuhan menyingkapkan diriNya. Karena membatasi Tuhan dalam satu bentuk agama déngan mengeluarkan agama yang lain adalah kekafiran, dan menyembah Tuhan dengan segala macam adalah jiwa agama yang benar. Inilah agama universal, suatu agama yang meliputi semua agama dan menyatukan semua kepercayaan. (Lihat: Kenneth W. Morgan, Islam Jalan Lurus, Pustaka Jaya, Jakarta, 1986, hal : 202) 
9) Menurut Abdul Karim Al-Jilli, segala yang wujud dalam'alam semesta ini tunduk pada Allah, baikdalam wujud perilaku dan ucapan, bahkan secara dzat dan sifat. Semua yang wujud ini adalah hamba-hamba Allah secara De Facto. Adanya perbedaan dalam ritual-ibadah yang terlimpah dalam agama-agama disebabkan oleh perbedaandeterminasi simbol-simbol dan sifat-sifat. Allah menampakkan diriNya dalam alam ini dengan melalui simbol yang samar dan wayuharti, sebagaimana juga Allah menampakkan diriNya dengan melalui simbol yang diskursif. Perwujudan kedua simbol inilah yang membawa aneka ragam penafsiran manusia. (Lihat : Abdul Karim Al-Jilli, Al-Insan AI-Kamil, Al-Ma'rifat Al-Awakhir Wa Al-Awail, Darul Fikri, Kairo, 1975, juz : 2, hal 119).

10) Dalam konteks ini menarik untuk dikaji adalah hasil interpretasi Syech Musthofa Al Maraghi terhadap makna hidayat. Menurut Al Maraghi, ada 5 macam dan tingkatan hidayat yang dianugerahkan Allah pada manusia : 1) Hidayat al-ilhami, gharizah atau instink.2)Hidayat Al-Hawas, indera. 3) Hidayat Al-Aqli, akal budi.4) Hidayat Al-Adyani, Agama 5) Hidayat Al-Taufịi. Hidayat akal budi lebih tinggi tingkatnya dari kedua hidayat yang lebih dulu, yakni instink dan indera yang dianugerahkan Tuhan pada hewan. Jadi, hidayat akal budilah yang memisahkan antara manusia dan hewan, yang merupakan kelebihan manusia. (Musthofa Al-Maraghi,Tafsir.Al Maraghi, juz I, Kairo; 1969, hal. 35)

Secara historis, sejak zaman Renessains, hal yang membedakan manusia dari makhluk-makhluk lain adalah fakta bahwa manusia itu mákhluk yang berakal. Bagi Plato, akal adalah untuk mengarahkan budi pekerti sedang menurut Aristoteles, akal adalah kekuatan yang tertinggi dari jiwa. Akal adalah sifat milik manusia yang memisahkannya dari watak nonmanusiawi. (Harold Titus, Persoalan-persoalan Filsafal, Bulan Bintang, Jakarta, 1984, hal.41).

11) Ciri utama manusia, ciri khasnya, bukan kodrat fisik atau kodrat metafisik, melainkan karyanya. Karyanyalah, sistem kegiatan-kegiatan manusiawilah, yang menentukan dan membatasi dunia "kèmanusiaan". Bahasa, mitos, religi, kesenian, sejarah, adalah sektor-sektor penting dalam duniaitu (Enst Cassirer, Manusiadan Kebudayaan, Granedia, Jakarta, 1987, hal. 104)

12) Alquran ( $51: 19),(70: 24)$
13) Alquran (107:1-3)

14) Alquran ( $2: 268)$

Islam 'sendiri telah mensyari'atkan kepada pemeluknya untuk berusaha mencari dan menghasilkan harta benda atau kekayaan, serta membolehkan terjadinya hubugnan mu'amalah, joi venture, dan perdagangan. Begitupun, Islam mewajibkan untuk menjaga dan memelihara harta kekayaan, mengharamkan perbuatan mencuri, penipuan, dan memakan harta benda orang lain dengan cara yang bathil, merusak harta orang lain, mengharamkan riba, menangkal kemadhorotan dan menahan harta milik orang yang bodoh. Harta benda dal am pandangan Islam merupakan salah satu dari 5 perkara yang dijamin dan dilindungi disamping agama, jiwa, akal, harga diri. (Lihat: Abdul Wahab Khollaf, Ilmu Ushul Al-Fighi, Darul Fikri, Kuwait, 1977, hal. 201)

15) Menurut Yusuf Qordhawi, dalam menganatarkan dan memberikan jaminan terhadap pemeluk-pemeluknya untuk menuju taraf hidupyang terhormat, Islam menyumbangkan berbagai cara dan jalan. Yaitu, pertama, bekerja. Kedua, mencukupi keluarga yang lemah. Ketiga, zakat. Keempat; dana perbendaharaan Islam dari berbagai" sumbernya. Kelima, keharusan memenuhi hak-hak selain zakat. Dan keenam, shodaqoh sukarela dan kebajikan individu. (Lihat : Yusuf Qordhawi, Problema KemiskinanApaKonsepIslam, Bina Ilmu, Surabaya, 1982, Hal. 61-217)

16) Masyarakat bersifat dinam is dan juga tak lengkap. Masyarakat mengalami perubahan, tidak sebab peribahan itu sendiri yang dapat diinginkan, tetapi oleh sebab setiap hal yang baru muncul secara baru dan belum pernah terjadi, sesuatu yang tidak pernah terjadi sebelumnya dan tidak akan terjadi lagi. Perubahan sosial itu tidaklah semata suatu penolakan terhadap hal yang lama, tetapi penerimaan terhadap kebaruan. Akibatnya, nilai baru itu hanya dapat dilihat berlawananan dengan latar unsur-unsur sistem nilai yang lebih lama yang dibawa oleh masyarakat. (Lihat : Forrest H. Peterson, A Philosophy of Man and Society, Philosophical Library, New York, 1970, hal : XIII).

17) F.Tonnies membedakan bentuk-bentuk pergaulan sosial/hidup menjadi dua yaitu : Gamernschaft, persekutuan hidup, masyarakat 
paguyuban, kesatuan sosial yang' hubungannya satu sama lain erat sekali, yang bersifat emosional dan organis. Kedua, Gesselchaft pergaulan hidup, masyarakat patembayan yaitu kesatuan sosial yang hubungan satu sama lain berdasar pamrih bersifat rasional dạn tidak organis (Lihat : George Ritzer, Sóciological Theory, Alfred A. Knopf, New York, 1983, hal : 23)

Durkheim menggunakan istilah solidaritas organis untuk menggambarkan interaksi sosial secara kekeluargaan dan egaliter dalam masyarakat primitf, serta solidaritas mekanisme untuk menggambarkan interaksi sosial yang fungsional yang terjadi di masyarakat modern. (Lihat : R.P. Cuzzort, EW King, Humanity and Modern Social Thought, the Dryden Press, USA, 1976 hal. 37)

18) Menurut Charris Waddy, Islam tidak pernah mewartakan penindasan dan menuntut bahwa inanusia harus tetap miskin. Disisi lain, Islam melarang pengumpulan kekayaan secara berlebihan sebagaimana tindakan eksploitasi. Eksploitasi inilah yang dikutuk oleh Islam jauh sebelum munculnya teori-teori modem. Islam justru berupaya membangun suatu masyarakat yang meletakkan dasar kesamaan dalam kesempatan dan kesamaan sosial. (Lihat : Charris Waddy, The Muslim Mind, Longman, London, 1982, hal : 53) 